\title{
Original DocumentsCharter of Confirmation by Richard Earl of Cornwall and Poictou of Grants of Land in the Honour of Berkhampstede, A.D. 1256
}

\author{
G. T. Clark
}

To cite this article: G. T. Clark (1877) Original DocumentsCharter of Confirmation by Richard Earl of Cornwall and Poictou of Grants of Land in the Honour of Berkhampstede, A.D. 1256, Archaeological Journal, 34:1, 180-186, DOI: 10.1080/00665983.1877.10851793

To link to this article: http://dx.doi.org/10.1080/00665983.1877.10851793

Published online: 14 Jul 2014.

Submit your article to this journal ¿

View related articles $\longleftarrow$ 
Driginal 国acuments.

\title{
CHARTER OF CONFIRMATION BY RICHARD EARL OF CORNWALL AND POICTOU OF GRANTS OF LANDS IN THE HONOUR OF BFRKHAMPSTEDE, A.D. 1256.
}

\author{
Communicated by G. T. CLARK.
}

The following charter is one of a large collection of similar documents and of private letters relating to the estates and family of the Verneys, still preserved at Claydon House, their ancient seat. The charter seems to have come into the possession of the family as one of the title deeds of the manor of Pendele or Pendley in the parish of Tring, which was the inheritance of Margaret Whittingham, who married John Verney in the reign of Edward IV, and was by him ancestress of Edmond Verney, who sold the manor in the reign of Elizabeth. It has been selected for publication on account of the strong local interest which attaches to it, for it contains the names of very many persons and places, mostly of and in the Hundred of Dacorum in Herts, and near to Tring. Had this document been known to Chauncy or Clutterbuck it would have enabled those industrious writers to give a far more perfect account of the descent of landed property in that division of their county.

Earl Richard, as Lord of the Honour of Berkhampstede, was chief lord of a sort of cape of the county of Hertford, about five miles broad at the base, and which extends to the north-west about eight miles into Buckinghamshire. Berkhampstede Castle stands at the base of this district, the parishes of Puttenham and Long Marston at its apex, and the town of Tring is included within it.

Mainly within this area a certain Rafe de Geyton ${ }^{1}$ had acquired divers lands by charters from their owners, and as they were all also within the Honour of Berkhampstead he brought their charters, six in number, before the over-lord for his confirmation, which, with the recitation of each of them, is here given.

Richard Plantagenet Earl of Cornwall and Poictou, better knuwn to posterity by his later title of King of the Romans, was the younger son of King John and brother of Henry III. He was born in 1209, and only eight years old at his brother's accession, by whom nine years later he was created Earl of Cornwall and Poictou. He was for a time heir to the throne, and always exercised great influence in the affairs of the kingdom. In the earlier part of the reign he sided with the Mareschals, and took up arms in their cause, marrying Isabel, daughter of the elder William Earl of Pembroke and widow of the Earl of Gloucester. He was a far wiser man than his brother, who seems to have consulted him on many occasions, although they were often at variance. No doubt his weight was much augmented by his

1 Probably of Gayton near Blisworth, where a family bearing the local surname was flourishing in the thirteenth and fourteenth centuries. There are fine effigies of Philip de Gayton (died 1316) and his wife Scholastica, and a diminutive figure of a child, in Gayton Church. 
immense wealth, a part of which he squandered in bribes to the German electors. To the Castle and Honour of Berkhampstede, the caput of his Hertfordshire possessions, he attached great importance, excepting the castle from the estates settled by him in dower on Saunchia of Provence. Wallingford, however, whence the charter is dated, was his chief seat, where he lived with great splendour.

The charter bears date the year before he became King of the Romans. In his latter days Earl Richard took part with the king, and commanded at Liewes, where he was made prisoner. Subsequently, after the surrender of Kenilworth, his counsels, in conjunction with those of Prince Edward, compelled Henry to be merciful, and laid the foundation of the good order by which the new reign was ushered in.

The Earl died at Berkhampstede April 2, i272, a little before his brother. Henry, his eldest son, died either before or just after him, childless, and Edward, his successor, died also childless in 1300, when the titles became extinct.

The charter contains thirty-nine lines, and is written upon a skin of parchment eighteen and a half inches broad by seventeen and threequarter inches long, polled at the top and folded at the bottom to carry the cord of the suspended seal. It is written in a clear hand, with good black ink, with the usual abbreviations, which are here, for the most part, expanded. It is quite perfect, save that in the twentieth line a strip of the membrane, about five inches long and a quarter of an inch wide, has been cut out, and is replaced by a slightly larger strip, which is neatly sewn in all round. Although this inserted strip is blank, the top of the letters of the following line run into it, and it is pretty evident that the whole defect is as old as the charter, and was caused by the clerk having made some blunder in the writing which he could not erase, and for the sake of which he did not care to begin his work over again. Probably the Earl's chancery clerks found their own parchment.

The seal is imperfect, but what remains is well cut and clear. It has been circular, three and one-eighth inches in diameter, of dark reddish wax, and about one-third of its most important part remains.

On the upper cide, that which corresponds with the face of the charter, is a knight on horseback galloping to the proper left. He wears a loose plaited surcoat, girdled at the waist, and with the skirt flowing freely backwards, shewing the right leg from the knee in armour, apparently mail, with a prick-spur. The right arm, in mail, is extended backwards, and holds upright a long straight sword. Above the upper edge of the surcoat is seen the throat, closely fitted with mail, and on the head a flat-topped helmet. The left arm is covered by a heater shield, which conceals the breast and bears a rampant lion, with probably a border. The saddle is raised before and behind, and the two girths cross saltire fashion under the horse's belly. Over the knight's right shoulder is a narrow embossed belt, for sword or dagger. The horse is cut with great freedom, and does not appear to be in armour. The legend is: "SIGIL[LUM RICARDI COMITIS CORNU]BIE."

Upon the obverse is a large, bold heater shield, about two inches high, bearing a lion rampant within a plain border, charged with fourteen roundels. Round and behind the shield is scroll work of an early 
English character. The legend, in place of the usual cross, commences with a crescent " SIG[ILLVM] RICARDI COMITIS[CORN] DBIE."

The seal is formed upon two plaited silk cords, either gilt or made with gold thread. The upper bend passes through four holes in the parchment, the lower ends are unravelled as tassels. A not very accurate engraving of Richard's seal is given by Sandford.

It is remarkable that Richard did not bear the arms of England, but took those of Poictou, "Argent, a lion rampant gules, crowned or," which he placed within "a border sable, bezantee," derived from the old Earls of Cornwall, and thus, as was not unusual, represented both his earldoms on his shield.

The present writer, not being familiar with the district, has failed to identify many of the persons and places named in the several charters. Almost all belung to the district, but most of the persons are tenants of the Earl, not tenants in capite, and consequently do not appear in the inquisitions or other records of the realm. Many of the places were those of private estates or farms, not of manors or parishes, and have been lost, and unfortunately there is no inquisition extant giving Earl Richard's estates at his death, and in which most of these local names would have appeared. What have been recovered have been found in Chauncy and Clutterbuck, in the Close, Patent, and Hundred Rolls, in the Testa de Nevile, and in similar records of the reign of Henry III. No doubt a further search on the spot, into parish terriers and estate maps, would shew many more of these names.-

"Onnibus ad quos presens scriptum pervenerit, Ricardus Comes Cornubie et Pictavie, salutem, noverit universitas vestra nos inspexisse cartam quam Galfridus de Lucy fecit Radulfo de Geyton in hec verba.

"ScLant presentes et futuri quod ego Galfridus de Lucy dedi concessi et hac presenti carta mea confirmavi Radulfo de Geyton, pro homagio et servicio suo, unam virgatam terre et dimidiam. et unam acram prati et dimidiam, in feodo meo de Wygenton; scilicet, illam terram quam Willielmus Basset, quondam de antecessoribus meis, tenuit in Wygenton; et predictum pratum sicut prescriptum est in Lolleseye; habend: et tenend: de me et heredibus meis sibi et heredibus suis aut suis assignatis, exceptis viris religiosis et Judeis, bene et integre, pacifice, cum suis pertinenciis, reddendo inde annuatim ipse et heredes sui mihi et heredibus meis sex solidos et octo denarios ad quatuor terminos anni, scilicet ad Festum Beate Marie in m....o, viginti denarios, et ad Nativitatem Sancti Baptiste, viginti denarios, et ad Festum Sancti Michaelis, viginti denarios, et ad Nativitatem Domini, viginti denarios, pro omni seculari servicio, salvo forinseco domini regis, quantum pertinet ad tantam terram in eodem manerio, pro hac autem donatione concessione et carte mee confirmacione dedit in manibus dictus Radulfus viginti marcas in Gersinnam.

"Et quia ego Galfridus de Lucy et heredes mei dictam terram et prenominatum pratum dicto Radulfo et heredibus suis sicut predictum est contra omnes nomines warantizare debemus, hanc cartam sigilli mei impressione roboravi, hiis testibus, Johanne de Merston, Roberto fratre suo, Iuliano de Chenduit, Symone de Bisevile, Will'mo de Audebur', Will'mo de Wederore, Alexandro de Wygenton, Waltero de Beledon, Rad: de Nevile, et aliis.

"Isspeximus et cartam quam Sylvester de la Grave fecit predicto Radulfo in hec verba. 
"Scian'r presentes et futuri quod ego Sylvest: de la Grave dedi concessi et hac presenti carta mea confirmavi Radulfo de Geyton pro homagio et servicio suo totam terram meam quam liabui vel habere potui in villa de Picheleston apud Yseleye cum omnibus suis pertinenciis in aliquo retenemento. Habend: et tenend: eidem Radulfo et heredibus suis vel cuicunque eam dare vel assignare voluerit de me et heredibus meis, libere quiete integre et plenarie, imperpetuum. Reddendo inde annuatim pro me et heredibus meis capitalibus dominis feodi illius, quatuor solidos et sex denarios ad tres terminos anni. scilicet ad Festum S'ti Andree octodecim denarios et ad Festum S'ti Marie in m.... octodecim denarios et ad Festum S'ti Petri ad vincula octodecim denarios, pro omni servicio, salvo forenseco servicio, et ego Silvest: et heredes mei warantizabimus predicto Radulfo et heredibus suis vel ejus assignatis totam predictam terram cum umnibus pertinenciis suis contra omnes gentes imperpetuum. Pro hac autem donacione et presentis carte mee confirmacione dedit mihi predictus Radulfus novem mareas argenti in Gersinnam, et ut hec mea donacio concessio et carte mee confirmacio rata et stabilis imperpetuum pleverit sigilli mei appositione eam roboravi. Hiis testibus Rad': Marescal':, Rob'to de Dalinghen: Rad': de Eston, Will'mo de Wylbesnade, Henrico de Dagenhale, Simone de Danevile, Adamo de Danevile, Will'mo de Audeburi, Rad: de Bratton clerico, et aliis.

"Inspeximus et cartam quam Frater Albanus Martel milicie Templi in Anglia minister fecit predicto Rad': in hec verba.

"OMNIBUs et fidelibus ad quos presens scriptum pervenerit Frater Albanus Martel milicie Templi in Anglia minister humilis salutem in domino. Sciatis quod nos de communi consilio et assensu capitali nostri in Pasch: apud Dinesle concessimus et hac presenti carta confirmavimus Rad': de Geyton et heredibus suis totam terram illam in villa de Pandele quod appellatur la inlande, cum toto Grascrofto et Pinnokeshulle, et cum omnibus aliis pertinenciis suis, et illud messuagium quod fuit Alfredi de Woderore cuin crofta que pertinet ad idem messuagium, et croftam illam que appellatur Clerke's croft, similiter croftam illam quam appellatur Mustelescroft, et croftam illam que appellatur la Stane, et totum, assartum in villa de Audeburi, quod est inter terram que fuit Will'mi filii Hugonis de la Grave ex una parte et les Hores ex altera similiter pasturam illam que jacet inter predictum assartum et fossatum quod se extendit ad Wyngate et inter les Hores ex una parte et Aylmerecrofte ex altera parte, et pasturam illam que jacet inter dictum fossatum quod est in superiori parte et viam que appellatur Pottereswey ex inferiori parte et vocatur pastura illa Saywedune et incipit a fine de Godwinstune et durat usque la Wyngate et de la Wyngate versus vallem usque ad pruam spinam, et de prua spina descendendo usque ad viam que appellatur Potteresweye videlicet usque ad illam locum ubi via que appellatur Mullesweye intrat in viam que appelatur Potteresweye et pratum illud quod est de quatuor acris in Lullesey et jacet inter aquam de Lullesey et pratum de Wingrave et circuitur ex omni parte de prato de Wengrave, et preterea totum jus quod habuimus de dono Hawysie de Bovill in communi bosco ubi Âbbas de la Feveresham et dominus Galfrid: de Lucy communicantur; concessimus et eidem Rad: et heredibus suis quietum de pannagio in bosco de Audeburi quum dedit nobis predicta Hawisia, et preterea decem solidos de dimidia hyda terre in villa de Chetendon que fuit Radulfi de Chetendon et homagium de terra Ricardi filii 
Will'mi Meynardi, et duos solidos et corpus suum et consuetudines cum tota sequela sua de terra Bartholomei de Beininden, duos solidos et quatuor denarios et corpus suum et consuetudines cum tota sequela sua de terra Hugonis Grom, sexdecim denarios et corpus suum et consuetudines cum tota sequela sua de terra Will'mi filii Godwini, quinque solidos et corpus sum et consuetudines cum tota sequela sua et totam terram illam quam appellatur Edithecrofte quam Willmus de Wederore tenuit, et totam terram illam quam Alfredus de Wederore tenuit, et totam terram quam Alfredus Juvenis tenuit, et totam terram quam Willmus de Bonteslye tenuit, que terre jacent inter dominacium antiquum et terras hominum de Pendele, et dimidiam virgatam terre quam Rad: de Bonteslye tenuit et corpus suum et sequelam suam, que scilicet omnia predicta tenementa habemus ex dono predicte Hawisie. Habenda et tenenda predicto Rad: et heredibus suis cum omnibus pert's, libere quiete et integre; reddendo inde annuatim domui nostre quinque solidus ad duos anni terminos scilicet duos solidos et sex denarios ad festum S'ti Mich's et duos solidos et sex denarios ad Pasch: Florum: et nos omnia predicta predicto Rad: et heredibus suis warantizabimus. Hiis testibus, domino Galfrido de Lucy, Rad: de Glanvile, Rad': marescal, Radulfo milite de Pichelestorn, G: : milite de ejusdem ville, Gregorio de Lembur', Alano de Hyda, Symone de Frangleye, Roberto de Marisco, Alex: filio Fulcher, Samuele de Wygenton, Johanne de Merston, et aliis

"Ixspexinus et cartam quam Ricardus Maresc: fecit predicto Radulfo in hec verba.

"Sciant presentes et futuri quod ego Ricardus Marescal' dedi concessi et hac presenti carta mea confirmavi Domino Radulfo de Geyton et heredibus suis vel cui dare vel assignare voluerit et quando, totam terram meam quam habui in villa de Magna Linford, in dominicis et redditibus in homagiis serviciis releviis et escaetis in pratis et pasturis in viis et semitis in boscis et planis et omnibus aliis dicte terre pertinentibus, vel que dicte terre pertinere possint pro homagio et servicio suo et pro sexaginta marcas argenti quas mihi pre manibus dedit: tenend: et habend: de me et heredibus meis sibi et heredibus suis vel aut dare vel assignare voluerit et quando in feodo et hereditate, libere quiete bene et in pace; reddendo ipse annnatim mihi et heredibus meis septem denarios, videlicet ad pascham, pro omni seculari consuetudine secta curie evictiones et demandas salvo forinseco servicio domini regis quando scutagium evenerit, scilicet quantum pertinet ad terciam partem unius feodi militis do proprio feodo de Morteyn; et ego predictus Ric: Maresc: et heredes mei warantizabimus acquietabimus et per predictum servicium defendemus predicto Rad: de Geyton et heredibus suis et eorum assignatis totam predictam terram cum omnibus suis pertin $\epsilon$ nciis nominatis et non nominatis contra umnes homines et feminas in perpetuum: et ut hec mea donacio concessio warantizatio et presentis carte mee confirmacio firma semper permaneat et stabilis eam sigilli mei impressione roboravi. Hiis testibus, Domino Stephano de Chenduit, Ivone de Picheleston, ... orante de Pichelestorn, Ric: de Molend', Will'mo de Audebur', Will'mo filio Philippi, Willmo filio Willmi Thuriet, et aliis.

"Inspexnmus et cartam quam Rogerus filius Ricardi de Dunesle fecit predicto Rad: in hec verba.

"Sciant presentes et futuri quod ego Rogerus filius Ricardi de Dunesley dedi concessi et hac presenti carta mea connrplavi Rad: de 
Geytone et heredibus suis pro servicio suo, dimidiam virgatam terre cum capitali mesuagio in Dunesle in parochia de Trenge, similiter cum capitali mesuagio in Dunesle similiter cum capite illius acre terre que jacet inter mesuagium predictum et mesuagium Radulfi Clerici de Dunesley et se habutat versus magnam viam in Dunesle, et etiam unam denarium redditus quam recipere solebam de Ricardo Coco de Dunesle de feodo predicti Radulfi, sine aliquo retenemento mihi vel heredibus meis de se vel heredibus suis : habend: et tenend: sibi et heredibus suis vel assignatis, libere quiete bene integre plenarie in pace et honorifice, in viis semitis pratis pascuis et pasturis et in omnibus locis, faciendo ipse Radulfus et heredes sui vel assignati capitali domino debitum servicium; pro hac autem donacione concessione et presentis carte mee confirmacione dedit mihi predictus Radulfus sex marcas et octo solidos et octo Denarios pre manibus; et ogo supradictus Rogerus et heredes mei vel assignati predictam dimidiam virgatam terre cum capitali mesuagio et capite acra et denariis redditus predicto Radulfo et heredibus suis vel assignatis contra omnes homines et feminas inperpetuum warantizabimus; et ut hec mea donacio firma sit et stabilis huic presenti carte sigillum meum apposui. Hiis testibus, Johanne Blundel, Thoma de Huntendon, Will'mo de Wedebore, Johanne Forestario de Trenge, Will'mo de Audebur', Will'mo Coco, Johanne de Dove, Willmo de Hamel, Ada Serviente de Pendele, Waltero Clerico de Wygenton, et aliis.

"Inspexmus et cartam quam Ricardus de Habinton fecit predicto Radulfo in hec verba.

"Sciant presentes et futuri quod ego Ricardus de Habinton dedi concessi et hac presenti carta mea confirmavi Radulfo de Geyton pro homagio et servicio suo totam terram meam quam Gilbertus calvus advunculus meus tenuit in Seybroc, in Pitcheleston, in Chetendon, cum omnibus pert's ad predictam pertinentibus : tenend: et habend: de me et heredibus meis dicto Rad: et heredibus suis vel assignatis, exceptis viris religiosis, libere quiete integre hereditarie; reddendo inde annuatim Simoni de Stukeli et heredibus suis ipse et heredes sui vel assignati sex solidos et octo denarios, scilicet ad festum St'e Marie in M.. tres solidos et quatuor denarios, et ad festum S'ti Michaelis tres solidos et quatuor denarios, et mihi et heredibus meis vel meis assignatis unum par cyrotecarum pro omni servicio, salvis duobus solidis solvendis pro quolibet scutagio quam scutagium currit per preceptum domini regis; et ego predictus Ricardus de Habinton et heredes mei vel mei assignati warantizabimus per predictum servicium dicto Radulfo et heredibus suis vel suis assignatis totam predictam terram cum omnibus suis pertinenciis contra omnes homines et feminas: pro hac autem donacione et concessione et warantizacione dedit mihi predictus Radulfus quinquaginta marcas argenti et ut hec mea donacio et concessio et warantizacio rata sit et stabilis presenti scripto sigillum meum apposui. Hiis testibus, Gileberto Greinvile, Johanne de Merston, Will'mo de Bello Cumpo, Nicholao Burdun, Militibus; 'Waltero de Belenden, Roberto de Merston, Will'mo de Wederore, Will'mo de Audeburi, Will'mo de Hamele, et aliis.

"NOS vero dictas donaciones et confirmaciones ratas et gratas habentes eas predicto Radulfo heredibus et assignatis suis quibuscunque, exceptis viris religiosis, pro nobis et heredibus nostris confirmavimus; habendas et tenendas prout predicte ante evidentius et plenius protestantur; in cujus rei testimonium presenti scripto sigillum meum 
apposuimus. Hiis testibus, Stephano de Chenduit, Rogero de Amari, Will'mo Russell, Milone de Belıo Campo, Will'mo de M'le, Roberto de Esthall, Will'mo Blundel, Will'mo Thuriet, et aliis. Datum apud Walingeford septimo die Julii anno gracie millesimo ducentesimo quinquagesimo sexto."

It will be seen that the charter commences and concludes with Earl Richard's confirmation of the contents to Ralph de Geyton, styled in one place Dominus, whom, however, he does not directly address. Of the Earl's witnesses, Stephen de Chenduit was the head of a family who had long held Charwelton and Middleton-Chenduit, corrupted into Cheyney, in Northamptonshire, and were tenants of the Honour of Berkhampstede. Hulian or Julian de Chenduit granted his manor of Ashridge with Pilston to Edmund Earl of Cornwall. In 1215 King John ordered the Constable of Berkhampstede to give to Rafe Chenduit seizin of his lands. The Amari family held lands under Wallingford, as did the Russells, in the fee of Mortaine, in Northamptonshire. Roger Amari held half a fee in Thornbury of the Earl of Warwick. Miles de Beauchamp held land at Lavenden, Bucks. Blundel was from Devon, and received from the elder Richard, Henry III's uncle, lands at Binstardeley, co. Northampton, which passed to his brother Robert as "Scutellarius" in the reign of Henry III. William Ilundel is described as " Cancellarius doruini comitis."

The Earl's part of the charter is very brief, and is confined to the introduction and conclusion, and a line introducing each of the six recited charters, to which his confirmation was necessary as over-lord of the Honour of Berkhampstede. All are in favour of Geyton.

Geoffrey de Lucy, the first grantor, conveys lands in Wygenton, and a meadow in Lollesey. He was a Baron of the realm, of Newington in Kent, the son and father of other Geoffries, the first and last Barons. He died 12th Edward I. They held Wygenton, and in Bucks lands in Chetendon. They also gave name to the manor of Lucy's in Little Gaddesden, which they conveyed to Earl Edmund when he founded a religious house at Ashridge. Wygenton is a parish and manor near Tring. Lollesey was near Albury. The Merstons of Merston, Beds, were local gentry. The Belendens were tenants of Feversham Abbey in Herts. Wm. Basset was probably of Adestoke, Bucks.

Pitcheleston or "torn" and Yseley, in the second charter, are, the one a parish, now Pichelestorn or Pitston, and the other a manor. De la Grace occurs at Chalfont St. Giles and in Gloucestershire.

Alban or Alan Martel, who grants the third charter, was in 1224 Master of the Temple in England, and Dinsley was one of their Preceptories. Of persons, Ralph de Glanvile was a Crovequer tenant, and the Hydes were an old family in Albury. The places named are probably in Tring parish. Chetendon or Cheddington, and Audeburi, Al- or Aldbury are parishes and manors near Berkhampstede. Wengrave is Wingrave, a manor in the Honour, but near Aylesbury.

Richard Mareschal, who grants the fourth charter, was of Great Linford near Newport Pagnel, as was Ralph, who was ordered in 1223 to hold Berkhampstede Castle. Rafe Chenduit was conjoined with him.

Dunesle or Dunsley, the land granted by the fifth charter, was in Tring. De Hamelo held lands in Herts under Feversham Abbey.

Of the persons in the last charter, Nicholas Burdun held Kings Teignton in Devon, and lands in Wilts, Gloucester, and Northampton. He was probably connected with Richard's earldom of Cornwall. 